\title{
DOI 10.26886/2414-634X.4(23)2018.6
}

UDC: $378.147: 004$

ART TECHNOLOGY IN THE FORMATION OF DESIGN CULTURE OF FUTURE TEACHERS OF LABOR STUDIES

\section{Yu. Kulinka, PhD in Pedagogical Sciences}

Kryvyi Rih state pedagogical University, Kryvyi Rih, Ukraine

This article presents the approaches to the understanding of the concept of "art-technology», describes the shape of the art technology for the formation of design culture of future teachers of labor studies; formulates author's definition of the art technology. The aim and the result of this study is to justify the methods of using art technologies in professional design training of future teachers of labor studies. The methods of art technique that can be used at the art lessons are proposed and tested in the process of professional design training of future teachers of labor studies.

Key words: art therapy, art pedagogy, art technologies, professional training, future teacher of labor training, art lesson, art situations.

Introduction. At the present stage of education reform one of the main tasks is to create the necessary conditions for the full development and self - realization of every Ukrainian citizen. It is possible to implement introducing new pedagogical technologies that would provide the features of the comprehensive development of the younger person, taking into account their individual differences to increase the effectiveness of cognitive activity.

The concept of a new education requires a system-activity approach to learning. Professional training of future teachers of labor studies is impossible to imagine without the introduction of professionally oriented 
technologies. Art technology is based on the activity approach and meets the standards of new creation. The orientation to the creative activity and the constant search of an own "l» is created using the art technologies in the process of professional design training of future teachers of labor studies.

General theoretical and methodological foundations of the art of pedagogy are represented in the scientific researches of R. Verkhovodova, T. Dobrovolska, A. Kozyr, V. Kokorenko, L. Komissarova, I. Levchenko, N. Miskova etc. Theoretical and methodical bases of training of art teachers are considered in their researches N. Sergeeva and L. Volkova; axiological foundations of art pedagogy in the training of future teachers is presented in the thesis of T. Kiseleva, O. Kondrytska etc.

Scientific ideas about the possibility of art technologies are based on the fundamental pedagogical researches. Among them: the concepts of pedagogic freedom and pedagogic support (O. Gazman); the organizing educational activities and sensory - developing means of awakening of creative activity (G. Gid, V. Lowenfeld, F. Cisen). However, the majority of specialists in the field of art pedagogy associate its forms and methods, first of all, with correctional social and pedagogical technologies, but not with the professional training of specialists in the field of education.

The results of theoretical and practical analysis of the problem of formation of design culture in future teachers of labor training by means of professionally-oriented technologies showed the existence of certain contradictions, in particular between: the objective need of society (at general and local levels) in the training of highly qualified teachers of labor training and the insufficient opportunities of modern technologies of design culture formation; the need to implement modern professionally-oriented technologies in the process of design culture formation of specialists and 
the availability of appropriate methodological developments as for the use of art technologies as a type of professionally-oriented technologies.

Purpose of article. So, the task of our study is to determine the possibility of implementing the methods of art pedagogy in the design culture formation of future teachers of labor training, to determine the method of using art technologies in labor training and to form the ability of future professionals to apply art technologies in practical design activities at the labor training lessons.

Statement of the main material. The general processes of humanization and humanitarization of education, on the one hand, and the possibilities of design in the professional development of specialists, future teachers of labor training, on the other, cause modern interest to the concept and content of art pedagogy in professional training of specialists.

The analysis of scientific literature suggests that art pedagogy is, in fact, a separate branch of pedagogical science, which integrates the potential of art, pedagogy and psychology for humanistic solutions of the problems of personal development, including professional. The art in art pedagogy plays a peculiar role of a mediator between a person and his profession; if we are talking about the training of future teachers of labor training, art pedagogy becomes both a special technology of professional training and an important means of forming a design culture.

Scientific discussions about the role of art in the formation of creative, artistic and intellectual personality have been going on for thousands of years. As a specific-artistic form of reflection of the world, the art has repeatedly acted as a means of harmonization of the human state of mind, has been a reliable source of spiritual formation of the individual and is considered as an obligatory component of youth education. And the art of the XXI century has expanded its functionality - there is «art therapy» - the technology of the purposeful use of art as a vehicle of psychotherapeutic 
and psychological effects on the person based on the belief that the inner self of a person is reproduced in visual form whenever she draws or deals with modeling, not too reflecting on the results of their work, that is, spontaneously, in contrast to the carefully structured learning activities [1, p. 217]. For the first time the British artist Andrian Hill used the term art therapy (art therapy literally means «therapy by art» in 1938 in describing his work with tuberculosis patients.

The technology of bringing art to the solution of educational tasks acquired the name «art-technology» in the pedagogical science. The developers of this industry of pedagogical knowledge - O. Bulatov, Zh. Valeeva, M. Guzeva, M. Katrenko, L. Lebedeva, V. Sokolova, etc. consider pedagogical resources of creativity in different aspects (education of students of different ages; socio-pedagogical activity with students who have certain developmental defects; art pedagogy in the system of technology of professional training).

The most detailed concept of "art pedagogy» and "art therapy» are delimited in the study of O. Soroka [5]. The researcher considers art pedagogy as a branch of knowledge that combines pedagogy and art and provides an opportunity to use art to solve professional socio-pedagogical problems without pursuing special goals of art education. Agreeing with this definition, we note that it is formulated based on the dominant beginning of art therapy; we also believe that art pedagogy can and must be used for the implementation of special goals of technological education and training of future teachers of labor training.

Art technology is an interdisciplinary branch of the theory and practice of pedagogical activity: it combines theoretical-methodological and technological tools of creativity, pedagogy, psychology, art, sociology, philosophy, and aesthetics and serves to integrate humanitarian knowledge in order to attract students to creative activities. 
Art technology in the modern world is developing in rather difficult conditions and has the ability to influence the formation of personality at different stages of its socialization and creative development. As L. Lebedeva points out rightly, art technology primarily involves working with a person by organizing a living constructive union of a child and an adult in the cultural space in order to implement the following educational tasks: the development of emotional and volitional sphere of students; the development of creativity as the ability to creativity and the need for creative expression; psychohygiene (care of the emotional and mental state of the student - reducing internal anxiety and aggression, mastering the skills of emotional self-regulation means of artistic and creative activity, etc.); the formation of a positive "I-concept» of the student on the basis of selfknowledge and self-perception; ensuring social and cultural adaptation, harmonization of personality development of the students in the context of the triad «nature - I-society» $[2$, p. 6].

Thus, on the basis of the scientific works analyzed by us, we can state that art technologies is a professionally-oriented system of installations that determine a special set and layout of forms, methods, techniques of integration of art, design and artistic and creative activity for solving the problems of professional design training of future teachers of labor training.

The use of art technologies at the lessons of labor training makes it possible to expand and deepen the level of cognitive activity, to awaken in a person the desire for in-depth study of the material, to develop creative abilities, to improve the quality of the educational process. The conceptual ideas of humanism, creativity, interactivity and reflexivity set the orientation for the practical activity of the teacher of labor training. This is the basis of the art-pedagogical lesson of labor training, designed to provide emotional well-being of students by means of art and artwork. 
According to T. Sokolova [4], the content of the art-pedagogical lesson is formed on the principle of «two-layer cake»: the content of the lesson theme is enriched with the content of this or that kind of art, which eventually integrate into each other and give the effect of optimizing mental activity, educational influence of the lesson content on the spiritual sphere of the student. The content of the labor-training lesson should include everything that a person needs to develop his or her own personality. To find oneself, an individual needs to choose and build his own world of values, enter the world of knowledge, master creative ways of solving scientific and life problems, open the world of reflection of his own «l» and learn to manage it.

According to this, when planning and conducting lessons of labor training using art technology, it is necessary to include mandatory components in its structure:

- axiological - introduces students to the world of values and helps them to choose a personally significant system of value orientations based on art;

- cognitive - provides students with scientific knowledge about man, culture, history, nature, noosphere as the basis of spiritual development (spiritualizes intellectual activity);

- activity-creative - contributes to the formation and development of students ' various ways of activity, creative abilities necessary for selfrealization of the individual in practical, scientific, artistic and other activities (integrates different types of human activity);

- personal (spiritual) - provides self-knowledge, development of the ability of reflection, mastering the ways of self-regulation, selfimprovement, moral self-determination, forms a life position (helps the student to meet with himself). 
The use of art technology at the lessons of labor training gives students the opportunity to express their own thoughts, feelings, emotions, develops creative abilities, gives a high positive emotional charge, forms an active life position, confidence in their abilities. The variants of art lessons can be: lessons, built on one form of art, when the laws of the genre are both teacher and students; lesson, which includes elements of art as a means of teacher activity; lesson, where the use of individual elements of different genres and types of arts as a way of organizing cognitive activity of students. This determines the structure of the art lesson. Two components should be clearly seen in the structure of the art lesson. The first is nonverbal, creative, unstructured, where the main activity is the process of creativity. The second part is the verbal interpretation of the created images, associations, emotions and feelings that arose during the work

Thus, the structure of the art lesson should consist of the following stages: 1) Setting up for work («warming up»); 2) Activation of various sensory spheres (visual, auditory, taste, olfactory, tactile, kinetic) and updating of visual, audio and kinesthetic images; 3) Individual creative work; 4) Stage of verbalization; 5) Final stage - reflective analysis.

Accounting periods of pupils' health at the lessons; the age and physiological characteristics of pupils in lessons; the presence of emotional unloading at the lessons; alternating of postures considering the type of work; the use of physical pauses are important while conducting of the art lessons of labor training.

We use the following techniques of art technology in the process of training future teachers of labor training:

«Collage» - a technique based on the gluing on any basis of materials that differ from it in color and texture. In contrast to the picture, collage involves more freedom of the author in the performance, for example, pasted pictures can go beyond the edge of the base, glued to each other, 
formed accordion, and the like. If there is no scissors, the picture can be «cut» by hands, giving them the desired shape. The main thing in the collage is not accuracy, but the ability to express your thoughts, ideas, your view and your understanding of the topic. Possible themes for collage at the lessons of labor training. For example: "Magazine collage technique». Using fragments of materials from various printed products to create a composition of clothes in the style of "oversize» in the form of a booklet, program or on a separate sheet of paper, followed by a discussion of the name and content of the created collage.

"Coat of arms» (on various subjects). The motto and coat of arms are symbols that enable a person to reflect in a concise manner the philosophy of life and his credo. This is one of the ways to make a person think, formulate, describe and present to others the most important ideas of his worldview. The technique of this method provides: on large sheets of paper with the help of paints or felt-tip pens, it is necessary to reflect your personal coat of arms and motto. You need to come up with something interesting that accurately conveys the content of life's aspirations, positions, understanding yourself, understanding your own «l», which is a necessary component in determining the future profession. To offer the techniques of the coat of arms with the use of different materials.

One of the most interesting and modern techniques in art technology is "Mandala», which translated from Sanskrit (mandala) "circle» or "center». Its pattern is symmetrical: usually it is a circle with a pronounced center. It is believed that when a person draws a mandala, he draws his inner world, state, his present, himself outside the society, his spiritual essence. She answers existential questions: Who am I? Where am I? Where I come from. Where am I? When the first two questions are answered, the situation is reassessed. At the lessons of labor training, it will be useful to use different 
materials: plastic caps, plastic bottles, beads, buttons, beads, natural material, working with this technique.

For the effective formation of the design culture of future teachers of labor training, there is the use of art-pedagogical situations, which in fact, are a kind of pedagogical situations that arise and are solved in the process of professional design training of future teachers of labor training. Because of the analysis of scientific literature, T. Rudenka defines the art pedagogical situation «as a kind of pedagogical situation, which implements the tasks of formation of professional competence by means of art» $[3, p$. 84].

Studying by the first year undergraduates of training course «Methods of specialized training" in the process of familiarization with the technological profile «Design basics» (topic 2.3. "Features of the educational process in the profile school»), future specialists solved a number of art-pedagogical situations, which allowed undergraduates not only to understand the content of the topic better, but also contributed to the formation of design culture and improve the level of training. For example, the activity "Dress a portrai». Purpose: the development of creative imagination. Material: a portrait, glued on cardboard or frame with dense material, colored paper, foil, pieces of fabric, fur and so on. Participants are invited to "dress» their hero with the help of applicative material. It is necessary to make a headdress (hat, scarf), to create jewelry, if it is the portrait of a woman, a girl (beads, earrings, bracelets, etc.), to come up with a suit (ball gown, national costume, sportswear, tailcoat, and the like). Come up with the name of the picture, the name and biography of his hero.

An evaluation of the results of the use of art technologies in the formation of design culture of future teachers of labor training showed that the use of this technique makes students work more effective. Performing creative art exercises and situations, students are more attuned to work, 
attentive and active, which contributes to the formation of their design culture.

The collected data indicate that working on this technique, future professionals perceive the information better, increases their attention, reduces fatigue and tension, and creates a positive emotional attitude. The level of knowledge is higher, and the development of skills - more effective. We compared the results of the formation of activity and creative thinking of future teachers of labor training in the process of professional design training (table. 1).

Thus, the results in the experimental group improved: the high level increased by $5 \%$, the average-increased by $7 \%$, and the low decreased by $11 \%$. The indicators of the control group have not changed in comparison. It becomes clear that the use of art technology helps to enhance the creative activity of students.

Table 1

The results of formation of cognitive activity and creative thinking of future teachers of labor training in the process of professional design training (in \%)

\begin{tabular}{|c|c|c|c|}
\hline Group & Low & Medium & High \\
\hline \multicolumn{4}{|c|}{ Levels of cognitive activity } \\
\hline Experimental group & 26,2 & 44,6 & 29,2 \\
\hline Control group & 32,5 & 43,6 & 23,9 \\
\hline \multicolumn{4}{|c|}{ Levels of creative thinking } \\
\hline Experimental group & 30,8 & 39,5 & 29,7 \\
\hline Control group & 34,4 & 43,3 & 22,3 \\
\hline
\end{tabular}

In order to identify the future teachers of labor training level of design culture in the experimental work, we used the analysis of art technology products that were made by students in the course of studying the discipline «methodology of profile training». The essence of the observation was to identify the following indicators: the degree of manifestation of knowledge in 
solving design problems and creating art objects; the degree of manifestation of independence; the degree of manifestation of project thinking; the degree of manifestation of creativity; the degree of aesthetic taste. The results of the test are shown in Fig. 1.

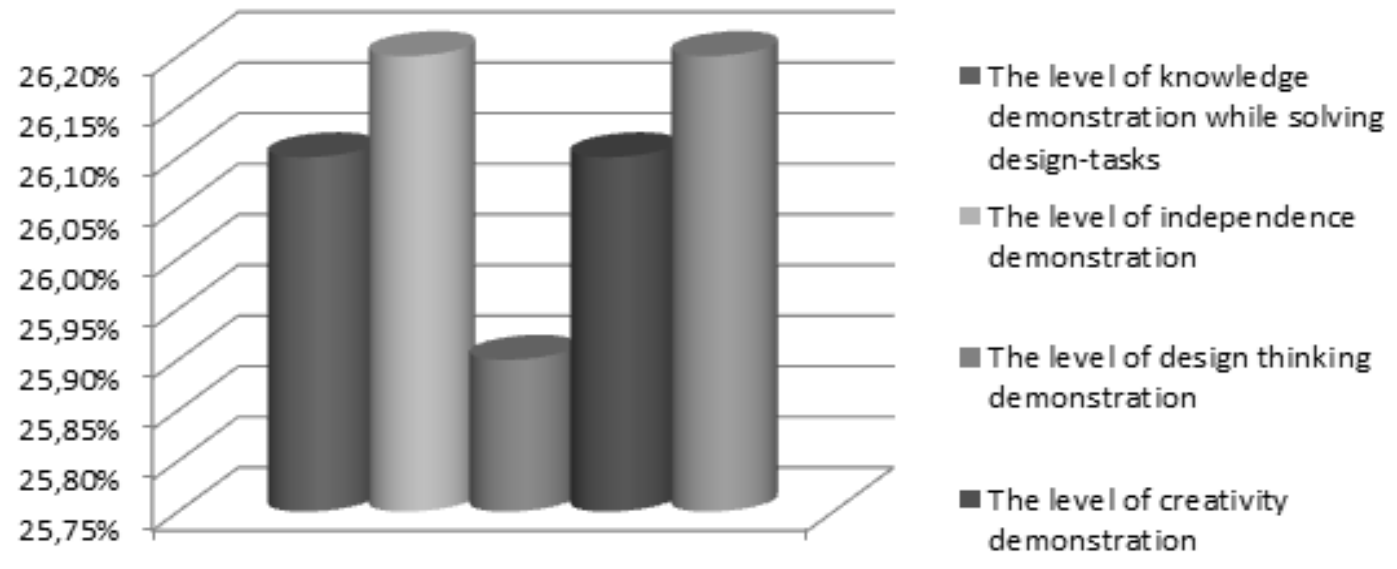

Fig. 1. Identification of the degree of manifestation of indicators of design culture by means of art technologies in future technology teachers

As you can see, the use of art technologies in order to form students ' design culture most affects the degree of manifestation of independence and creativity of future teachers of labor training.

Summary. Therefore, the proposed art techniques and methods will help to reveal the creative potential of students, which will certainly affect the level of training, will develop the skills of design activities, to overcome social alienation, to build harmonious relationships and contribute to the formation of design culture of future teachers of labor training. Because of scientific research in the field of art pedagogy, it is proved the interdisciplinary nature of the latter in the context of design. It is found that the use of art technology plays an important role in the formation of the design culture of future teachers of labor training, as it provides emotional and sensory perception of information and activation of the subject position based on design. 
We see the prospects for further research in the need for a comprehensive justification of the expected results of the development of design culture of future teachers of labor training and technology by means of professionally oriented technologies and the corresponding construction of the educational process in the pedagogical institution of higher education.

\section{Literature:}

1. Вознесенська О. Особливості арт-терапії як методу /

О. Вознесенська // Психолог. - 2005. - № 39. - С. 6-8.

2. Сорока О. В. Категоріальне розмежування понять «арт-терапія» $i$ «арт-педагогіка» / О. В. Сорока // Науковий вісник Національного університету біоресурсів і природокористування України: зб. наук. пр. / Національний університет біоресурсів і природокористування України; [ред. кол.: Д. О. Мельничук [та ін.]]. - Вип.155, Ч.2. - 2010. C. 165-173.

3. Лебедева Л. Д. Арт-терапия в педагогике / Л. Д. Лебедева // Педагогика. - 2000. - № 39. - С. 5-8.

4. Соколова Т. А. Артпедагогика как инновационная сфрера научного знания и педагогической практики [Електронний ресурс] / Т. А. Соколова. - Режим доступу:

http://istina.msu.ru/profile/etsokolova/.

5. Руденька Т.М. Формування профресійної компетентності майбутніх фрахівців мистецьких спеціальностей засобами артпедагогіки: дис. ... канд. педагогічних наук: 13.00 .04 / Тетяна Миколаївна Руденька. - Житомир, 2017. - 237 с.

\section{References:}

1. Voznesens`ka O. Osobly`vosti art-terapiyi yak metodu // Psy`xolog. 2005. - № 39. - P. 6-8. 
2. Soroka O. V. Kategorial'ne rozmezhuvannya ponyat "art-terapiya» $i$ «art-pedagogika» // Naukovy`j visny’k Nacional'nogo universy'tetu bioresursiv i pry rodokory`stuvannya Ukrayiny`: zb. nauk. pr. / Nacional `ny j universy`tet bioresursiv i pry`rodokory`stuvannya Ukrayiny`. - Vy`p.155, Ch.2. - 2010. - P. 165-173.

3. Lebedeva L. D. Art-terapy`ya v pedagogy`ke // Pedagogy`ka. - 2000. № 39. - P. 5-8.

4. Sokolova T. A. Artpedagogy`ka kak y'nnovacy’onnaya sfera nauchnogo znany`ya y` pedagogy 'cheskoj prakty`ky` [Elektronny`j resurs] - Rezhy`m dostupu: http://istina.msu.ru/profile/etsokolova/.

5. Ruden'ka T. M. Formuvannya profesijnoyi kompetentnosti majbutnix faxivciv my`stecz`ky`x special'nostej zasobamy` art-pedagogiky`: dy`s. ... kand. pedagogichny`x nauk: 13.00.04 / Tetyana My`kolayivna Ruden`ka. Zhy`tomy`r, 2017. - $237 p$. 